UDC 378.014.5.004

Petro M. Boichuk

Ph.D. in Pedagogy, Director

Lutsk Pedagogical College, Lutsk, Ukraine

ORCID ID 0000-0003-4863-980X

petroboychuk@i.ua

Olha L. Fast

Ph.D. in Pedagogy, Postdoctoral Researcher

Lesya Ukrainka East European National University, Lutsk, Ukraine

ORCID ID 0000-0001-7216-0044

olhafast.ua@gmail.com

\title{
ORGANIZATIONAL CULTURE AND TECHNOLOGY-INFUSED MANAGEMENT IN HIGHER EDUCATION: THEORETICAL AND EMPIRICAL ASPECTS
}

\begin{abstract}
The paper provides an overview of the research sources, methodology and main findings of the research of a higher educational institution organizational culture and technologyinfused management correlation. Based on the recent research, the authors provided the definition of the organizational culture concept. The research revealed that the current organizational culture of the Lutsk Pedagogical College is more like market culture. The respondents in the present study defined the adhocracy culture as the desirable organizational culture in the College. Notably, the results of the in-depth interview based on expert assessment method indicated that teachers were moderately satisfied with the level of competence of the administrative staff to meet challenges of technology-infused management at their higher educational institution.
\end{abstract}

Keywords: organizational culture; technology-infused management in higher education; ICT application tools; leadership.

\section{INTRODUCTION}

An increasingly competitive market, globalization and internationalization trends have brought about new challenges for many higher educational institutions (HEI). To be successful in the 21 st century means to be able to flexibly and effectively meet the requirements of a dynamically changing society. 'No organization in the twenty-first century would boast about its constancy, sameness, or status quo compared to ten years ago. Stability is interpreted more often as stagnation than steadiness, and organizations that are not in the business of change and transition are generally viewed as recalcitrant' (K. Cameron, R. Quinn) [1].

To cope with such a changing environment, called by researchers as 'age of turbulence' [6], HEI organizational cultures as well as their readiness to provide information and communication technologies-infused practices are expected to play the crucial role in higher education quality assurance. Starting from the 2014-2016 reform packages, the landscape of higher education in Ukraine is being intensely transformed. In the spirit of these transformations, higher educational institutions, being a specific type of organizations with also a specific organizational culture, are forced to re-think the strategies which enable effective educational management.

The organizational culture theory was initially developed on a psychological basis. Edgar H. Schein (1992) defined organizational culture as 'a set of basic tacit assumptions about how the world is and ought to be that a group of people share and that determines their perceptions, thoughts, feelings and, to some degree, their overt behavior' [2]. Edgar H. Schein and many other researchers described a shared vision that 'the values, beliefs, convictions and 
assumptions either invented, discovered, or developed, usually shared and accepted and necessarily respected by the members of a particular organization should be interpreted as rules and norms that explain why and how that organization gets formed and structured, functions and lasts' [3].

Statement of the problem. This paper reports on a study in which diagnostic interventions into the information and communication technology-infused educational management as well as the process of HEI organizational culture establishment were investigated. As the concept of HEI organizational culture is used in a variety of research discourses, it was found that the concept was not always clearly defined. These findings - as well as the growing attention to the comprehensive integration of ICTs to promote excellence and support transformation of HEI organizational culture and the attempts to develop the technology-infused management in higher education - beg the question: what is the current state of affairs concerning organizational culture and the digital-age resources use in higher education management in Ukraine at a local level? Taking this into account, we formulated the following central research question: what are the current and the desired organizational cultures at Lutsk Pedagogical College, and how ICT tools affect the staff's desired organizational culture establishment?

The underlying research questions we also formulated in this specific project were: what is the HEI organizational culture and how do we interpret this concept in our research? What research approaches to differentiation of organizational culture archetypes exist and how do they correlate? What is the relationship between the College organizational culture type and its administrative staff and teachers' competence to meet technology-infused HEI management challenges?

Analysis of recent research and publications. In the educational management literature the organizational culture concept has enjoyed limited but increasing attention in several strands. It is presented in higher education quality assurance literature as a key component of quality culture in universities [17-20; 22; 25]. From the angle of HEI organization and quality management literature, organizational culture is seen as the "social glue' binding an organization together [1-3; 6-8]. A body of international empirical research now exists which argues the importance of effective management due to the establishment of an appropriate organizational culture at a HEI [7-8; 14-29]. These studies provide valuable insights that organizational culture can be 'reflected in terms of collaboration, trust and learning' [18]; an appropriate culture can 'encourage people to create and share knowledge within an organization' [14]. In this regard, G. Bendermacher, M. Egbrink et al. stated that 'higher education institutions should nurture a quality culture in which structural/managerial and cultural/psychological elements act in synergy to continuously improve education' [5]. Furthermore, many studies have found that innovation, a shared vision for purposeful change, and the efforts to use technology creatively and proficiently depend on HEI organizational culture $[6 ; 9 ; 18 ; 28]$.

The purpose of the present article is to: briefly review the theoretical foundation of organizational culture and provide content analysis of the concept through the foreign and domestic research; discuss important substantive implications stemming from organizational culture empiric research that may advance the field of ICTs implementation issues in educational management.

\section{METHODS}

Participants of this study were 63 respondents (administrative staff and teachers) of Lutsk Pedagogical College. Among them, 51 were females, 12 were males; 30 were college administrators and 33 were teachers. 
As the research instruments the following ones were used:

- content analysis method in order to provide the definition of HEI organizational culture concept;

- slightly modified and translated into Ukrainian (by the authors) Organizational Culture Assessment Instrument (OCAI) questionnaire, a validated tool for measuring current and preferred organizational culture developed by professors Kim S. Cameron and Robert E. Quinn of the University of Michigan;

- the in-depth interview of administrative staff and teachers. The questionnaire items were based mainly on the Information Technology Standards for Educational Leaders (translated into Ukrainian by the authors) and modified to fit to the nature of this study. The interview included the use of an expert assessment method to determine the level of competence of the administrative staff to meet technology-infused HEI management challenges.

\section{FINDINGS}

Historically, the E. Schein's approach has influenced the study of organizational culture (Table 1). Consistent with the general formulation of organizational culture, foreign and domestic researchers defined this notion within different research approaches: cultural (E. Schein, M. Kalnitska), social (G. Hofstede, J. Ruegg-Strum, G. Jones, L. Karamushka), and pragmatic (G. Morgan, V. Zotic, N. Horbenko, T. Koicheva). Clearly the study of educational management and organizational culture in higher educational institutions (HEIs) has born much fruit. However, organizational culture is the subject of current debate among the domestic researchers concerning its meaning, structure and diagnostics. Above all, the discussion has centred on the issue of differentiating the meaning of organizational culture and corporate culture notions. Some authors tend to equal the essence of these concepts (M. Kalnitska, T. Koicheva and others), which contradicts the established approaches of foreign researchers [9-12]. In an effort to bring some coherence to this discussion, we developed our own definition considering the conceptual elements of organizational culture, highlighted in Table 1. In our study we interpret organizational culture as a complex concept determined by the ability and readiness of a higher educational institution to mobilize the system of its internal and external resources (values, norms, and beliefs, traditions, rules etc.) in order to achieve strategic goals and mission, and to satisfy the requests of internal (students, teachers and staff) and external (government, quality assurance agencies, employers, parents) stakeholders.

Table 1

\section{Content analysis of the concept organizational culture through the foreign and domestic research}

\begin{tabular}{lll}
\hline \multicolumn{1}{c}{ Researcher } & \multicolumn{1}{c}{ Definition } & Conceptual elements \\
\hline E. Schein [7] & $\begin{array}{l}\text { Organizational culture is a pattern of shared } \\
\text { basic assumptions that the group learned as it } \\
\text { solved its problems of external adaptation and } \\
\text { internal integration that has worked well } \\
\text { enough to be considered valid. }\end{array}$ & $\begin{array}{l}\text { Assumptions } \\
\text { Values of external } \\
\text { adaptation } \\
\text { and internal } \\
\text { integration }\end{array}$ \\
G. Hofstede [7] & $\begin{array}{l}\text { Organizational culture is mental coding which } \\
\text { allows acting coherently; it can be described } \\
\text { according to symbols, heroes, values and } \\
\text { rituals. }\end{array}$ & $\begin{array}{l}\text { Coherentness } \\
\text { Values } \\
\text { Artefacts }\end{array}$ \\
\hline
\end{tabular}




\begin{tabular}{|lll}
\hline J. Ruegg-Sturm & $\begin{array}{l}\text { Culture is comparable with grammar rules and } \\
\text { semantic regulations of a language. }\end{array}$ & $\begin{array}{l}\text { Language culture } \\
\text { (communication } \\
\text { habits, values, norms, } \\
\text { opinions and attitudes, } \\
\text { stories and myths) }\end{array}$ \\
\hline G. Jones [8] & $\begin{array}{l}\text { Organizational culture is the set of shared } \\
\text { values and norms that controls organizational } \\
\text { members' interactions with each other and } \\
\text { with people outside the organization. }\end{array}$ & $\begin{array}{l}\text { Values } \\
\text { Norms }\end{array}$ \\
\hline
\end{tabular}

G. Morgan [7] Organizational culture is a social and collective phenomenon which refers to the ideas and values of a social group and is

Ideas

influencing their actions without them noticing Influence

T. Beneda [13] Organizational culture represents a system of values, beliefs, norms and rules that are accepted and shared by the majority of the staff and which are based on general cultural level of a society, norms of morality, and educational practice.

\begin{tabular}{|c|c|c|}
\hline $\begin{array}{l}\text { N. Horbenko } \\
\text { [11] }\end{array}$ & $\begin{array}{l}\text { Organizational culture includes such structural } \\
\text { elements: artefacts, values, norms, goals and } \\
\text { mission of the organization; the signs of a } \\
\text { university as a corporation; and competitive } \\
\text { environment as the value of social identity } \\
\text { formation. }\end{array}$ & $\begin{array}{l}\text { Artefacts } \\
\text { Values } \\
\text { Mission } \\
\text { Signs of a university }\end{array}$ \\
\hline
\end{tabular}

L. Karamushka Organizational culture is presented as a certain [6] hierarchy of values, rules, norms, traditions, ceremonies and rituals that are accepted in the educational institution and adhered to by its members.

Cultural level

Morality

Educational practice

Shared values

Norms

Traditions

\section{T. Koicheva} [12]

(Organizational (corporate) culture reflects values and unity of lecturers and students' ambitions for achieving common goals, considering these goals as a generally accepted mission.

M. Kalnitska [9]

Organizational culture is a model of the key values, beliefs and norms which are common to all the members of the team and which are transmitted to the new members of a team as definitely true and correct.

V. Zotic [10]

Organizational culture is a set of defined goals, values, norms, rules of behaviour and sanctions established by the organization.
Mission

Values

Unity

Values

Attitudes

Goal-setting

Rules of behaviour

Drawing on the literature and our previous studies, the present study assesses organizational culture of higher education institutions in the dimensions of goal orientation, innovation orientation, and participation in decision making, structured leadership, supportive leadership, shared vision, and collaboration among members. 
M.L. Lacatus concluded that the most important functions of the organization culture are:

- it is communicated, taught and transferred to members;

- it helps an organization to adapt to environmental circumstances and integrate internally;

- it works like a solving problem framework or guide, and even as a tool meant to enhance the functioning of the organization as well as its decision making process, performance, effectiveness and competitive position [14].

According to C. O'Reilly, organizational culture is nurtured and shaped gradually over a period of time, reflected in terms of collaboration, trust and learning, and it can shape the behaviours of people in that organization $[15 ; 18]$.

Moreover, in the educational context, organizational culture is related to both students' and teachers' values and beliefs, which affect the teaching and learning process (G.Marcoulides et al.) [16]. According to R. Hofman, organizational culture in HEI can and should be supportive to produce a supportive institutional environment that can facilitate teachers' innovations and student academic achievement [17; 18].

In spite of the definition confusion, organizational culture still emerged as a worthy variable in educational research. Importantly, there are many different approaches to university culture assessment (differentiation):

- Collegial, hierarchical, anarchical and political types of culture (T. Becher) [19];

- Culture of dynamism and culture of externalism (N. Fjorfort and J. Smart) [20];

- Strong organizational culture and weak organizational culture (B. Sporn) [21];

- Adhocracy culture, clan culture, hierarchy culture and market culture (K. Cameron and R.Quinn) [1];

- Enterprise, corporate, collegiate, and bureaucratic cultures (Ian McNay's)[22].

Recent developments in the study of organizational culture and attempts to take a broader, more comprehensive look at this notion contributed to the development of a matrix of organizational cultures, generally acknowledged under the name of Competing Values Framework.

The Competing Values Framework provides the definition of organizational culture grounded on the two value criteria: 1) internal (people) or external (organization) focus, and 2) stability (control) or flexibility (change).

Many scholars have stated that the Competing Values Framework (CVF) is a matrix of four quadrants resulting from crossing the essential dimensions that any organization may display $[14 ; 15 ; 20]$. According to O. Beytekin, the horizontal dimension presents transformation from cultures with internal emphasis, short-term orientation, and smoothing activities to cultures with an emphasis on external positioning, long-term orientation, and achievement-oriented activities. Within the matrix the vertical dimension refers to cultures characterized by flexibility, individuality, and spontaneity at one end and cultures characterized by stability, control, and predictability at the other end [23]. In figure 1, the basic attributes of four cultural archetypes, identified on the K. Cameron's matrix basis [24] and created along these two value dimensions are depicted. 


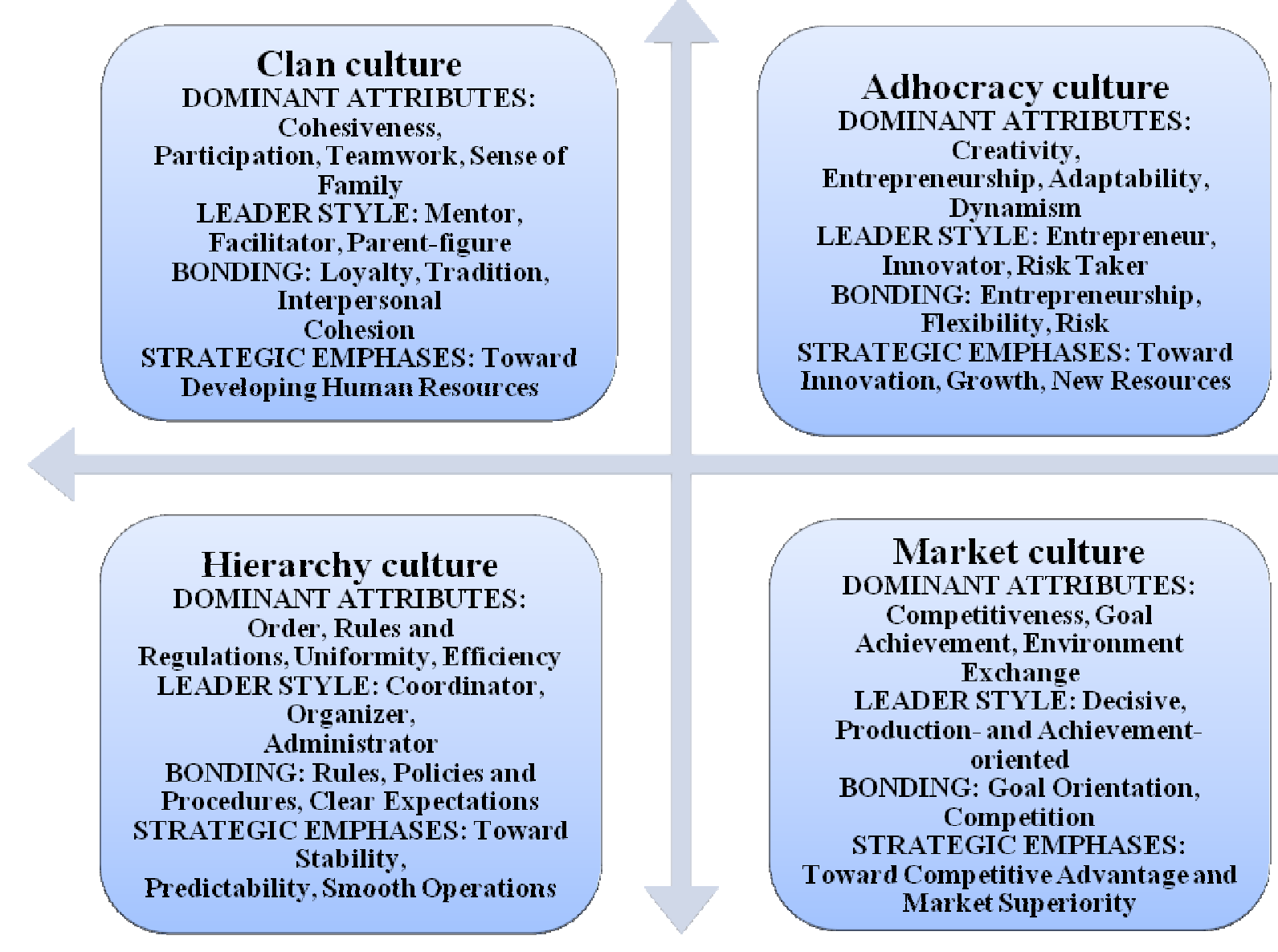

Fig.1. Organizational culture archetypes (Adapted from Lacatus, 2013 [14, 423])

M. Millington and J. Schultz [25] also revealed similar findings on organizational culture. It should be admitted that organizational cultures vary along both dimensions in unlimited possible ways. All four values can positively affect organizational function, depending on the conditions (D. Denison \& A. Mishra) [26].

form and intensity of control and the focus on policy and strategy are shown to be two particular dimensions of Ian McNay's model aiming at describing organizational culture of higher education institutions (HEI) [22]. According to I. McNay's model, organizational culture of any HEI can be classified into four types:

- Enterprise, consisting of firm policy and loose operational control, focus on market, external opportunities, and relationships with stakeholders;

- Corporate, consisting of tight policy and operational control, dominance of senior management, executive authority;

- Collegiate, consisting of loose policy and loose operational control, decentralization, focus on individual freedom;

- Bureaucratic, consisting of loose policy and tight operational control, focus on rules, regulations, and precedents [14].

Over the past two decades, the university cultural models characteristics were much detailed on the basis of the I. McNay's matrix. In particular, J. Jameson has created an analytical map for the differentiation of the organizational culture types presented in Table 2 $[14 ; 22 ; 28]$ : 
University culture models and their characteristics map (McNay; Jameson)

\begin{tabular}{|c|c|c|c|c|}
\hline Model Factor & $\begin{array}{l}\text { Collegial } \\
\text { culture }\end{array}$ & $\begin{array}{l}\text { Bureaucratic } \\
\text { culture }\end{array}$ & $\begin{array}{l}\text { Corporate } \\
\text { culture }\end{array}$ & $\begin{array}{l}\text { Enterprise } \\
\text { culture }\end{array}$ \\
\hline $\begin{array}{l}\text { Dominant } \\
\text { value }\end{array}$ & Freedom & Equity & Loyalty & Competence \\
\hline $\begin{array}{l}\text { Role of central } \\
\text { authorities }\end{array}$ & Permissive & Regulatory & Directive & Supportive \\
\hline Dominant unit & $\begin{array}{l}\text { Department/ } \\
\text { Individual }\end{array}$ & $\begin{array}{l}\text { Faculty/ } \\
\text { Committees }\end{array}$ & $\begin{array}{l}\text { Institution/ } \\
\text { Senior M'gement } \\
\text { Team }\end{array}$ & $\begin{array}{l}\text { Sub-unit/ } \\
\text { Project teams }\end{array}$ \\
\hline Decision areas & $\begin{array}{l}\text { Informal } \\
\text { group } \\
\text { networks }\end{array}$ & $\begin{array}{l}\text { Committees and } \\
\text { administrative } \\
\text { briefings }\end{array}$ & $\begin{array}{l}\text { Working parties } \\
\text { and Senior } \\
\text { M'gement Team }\end{array}$ & Project teams \\
\hline $\begin{array}{l}\text { Management } \\
\text { style }\end{array}$ & Consensual & $\begin{array}{l}\text { Formal } \\
/ \ll \text { Rational» }\end{array}$ & $\begin{array}{l}\text { Political } \\
\text { / Tactical }\end{array}$ & $\begin{array}{l}\text { Developed } \\
\text { leadership }\end{array}$ \\
\hline Timeframe & Long & Cyclic & $\begin{array}{l}\text { Short / } \\
\text { Mid-term }\end{array}$ & Instant \\
\hline $\begin{array}{l}\text { Environmental } \\
\text { fit }\end{array}$ & Evolution & Stability & Crisis & Turbulence \\
\hline $\begin{array}{l}\text { Nature of } \\
\text { change }\end{array}$ & $\begin{array}{l}\text { Organic } \\
\text { innovation }\end{array}$ & $\begin{array}{l}\text { Reactive } \\
\text { adaptation }\end{array}$ & $\begin{array}{l}\text { Proactive } \\
\text { transformation }\end{array}$ & $\begin{array}{l}\text { Tactical } \\
\text { flexibility }\end{array}$ \\
\hline $\begin{array}{l}\text { External } \\
\text { referents }\end{array}$ & $\begin{array}{l}\text { Invisible } \\
\text { college }\end{array}$ & $\begin{array}{l}\text { Regulatory } \\
\text { bodies }\end{array}$ & $\begin{array}{l}\text { Policymakers } \\
\text { as opinion leaders }\end{array}$ & $\begin{array}{l}\text { Clients / } \\
\text { sponsors }\end{array}$ \\
\hline $\begin{array}{l}\text { Internal } \\
\text { reference }\end{array}$ & Discipline & Rules & Plans & $\begin{array}{l}\text { Market } \\
\text { strength } \\
\text { / students }\end{array}$ \\
\hline $\begin{array}{l}\text { Basis for } \\
\text { evaluation }\end{array}$ & $\begin{array}{l}\text { Peer } \\
\text { assessment }\end{array}$ & $\begin{array}{l}\text { Audit } \\
\text { of procedures }\end{array}$ & $\begin{array}{l}\text { Performance } \\
\text { indicators }\end{array}$ & $\begin{array}{l}\text { Repeat } \\
\text { business }\end{array}$ \\
\hline Student status & $\begin{array}{l}\text { Apprentice } \\
\text { academic }\end{array}$ & Statistic & $\begin{array}{l}\text { Unit } \\
\text { of resource }\end{array}$ & Customer \\
\hline $\begin{array}{l}\text { Administrator } \\
\text { role- servant of } \\
\text {... }\end{array}$ & $\begin{array}{l}\text {...the } \\
\text { Community }\end{array}$ & ...the Committee & $\begin{array}{l}\text {...the Chief } \\
\text { Executive }\end{array}$ & $\begin{array}{l}\text {...the Client } \\
\text { (internal and } \\
\text { external) }\end{array}$ \\
\hline
\end{tabular}

Given the current and potential educational value of organizational culture construct, efforts to impact changes in educational management would be valuable in moving HEI organizational culture research through empirical measuring. Little experimental or long-term intervention research has been conducted in this area. The paper by I. Lapina, I. Kairisa and D. Aramina deals with the issue of evaluation of theoretical aspects of organizational culture and quality management, their interrelation and impact on continuous development of the University. As part of their research the authors used a modified version of the Organizational Culture Assessment Instrument (OCAI), a validated tool for measuring current and preferred organizational culture in Riga Technical University [27]. OCAI was developed by professors 
Kim S. Cameron and Robert E. Quinn of the University of Michigan as a modified version of the Competing Values Framework [1].

In 2017, the authors conducted an organizational culture research aiming at diagnosing existing and desired organizational culture types. Participants of this study were 63 respondents (administrative staff and teachers) of Lutsk Pedagogical College. As a research instrument was used slightly modified and translated into Ukrainian OCAI questionnaire. A sample item was: 'The organization is a very personal place. It is like an extended family. People seem to share a lot of themselves'. The format for all items in the survey was a 2-point scale, including now and preferred. Importantly, OCAI consists of the key organizational culture factors: dominant characteristics, organizational leadership, and management of employees, organization glue, strategic emphases, and criteria of success [1].

Taken together, the results of the respondents' opinions revealed that the current organizational culture of the College is more like market culture or rational culture (see Figure 2). Market oriented cultures are structured and controlled, with a focus on competing, flexibility, mobility, and productivity. Further, most respondents estimate the College as a result-oriented workplace, where the leaders are tough, demanding and hard-driving producers and competitors.

The respondents in the present study define the adhocracy culture as the desirable organizational culture in the College. This cultural type can be characterized as competence oriented, with a supportive role of central authorities. In this context, the College can be characterized as a dynamic, entrepreneurial, and creative workplace. Effective leadership is expected to be visionary, innovative and risk-oriented. Success, according to the respondents' opinions, is associated with producing unique and original products and services (teaching and learning methods, techniques, and technologies).

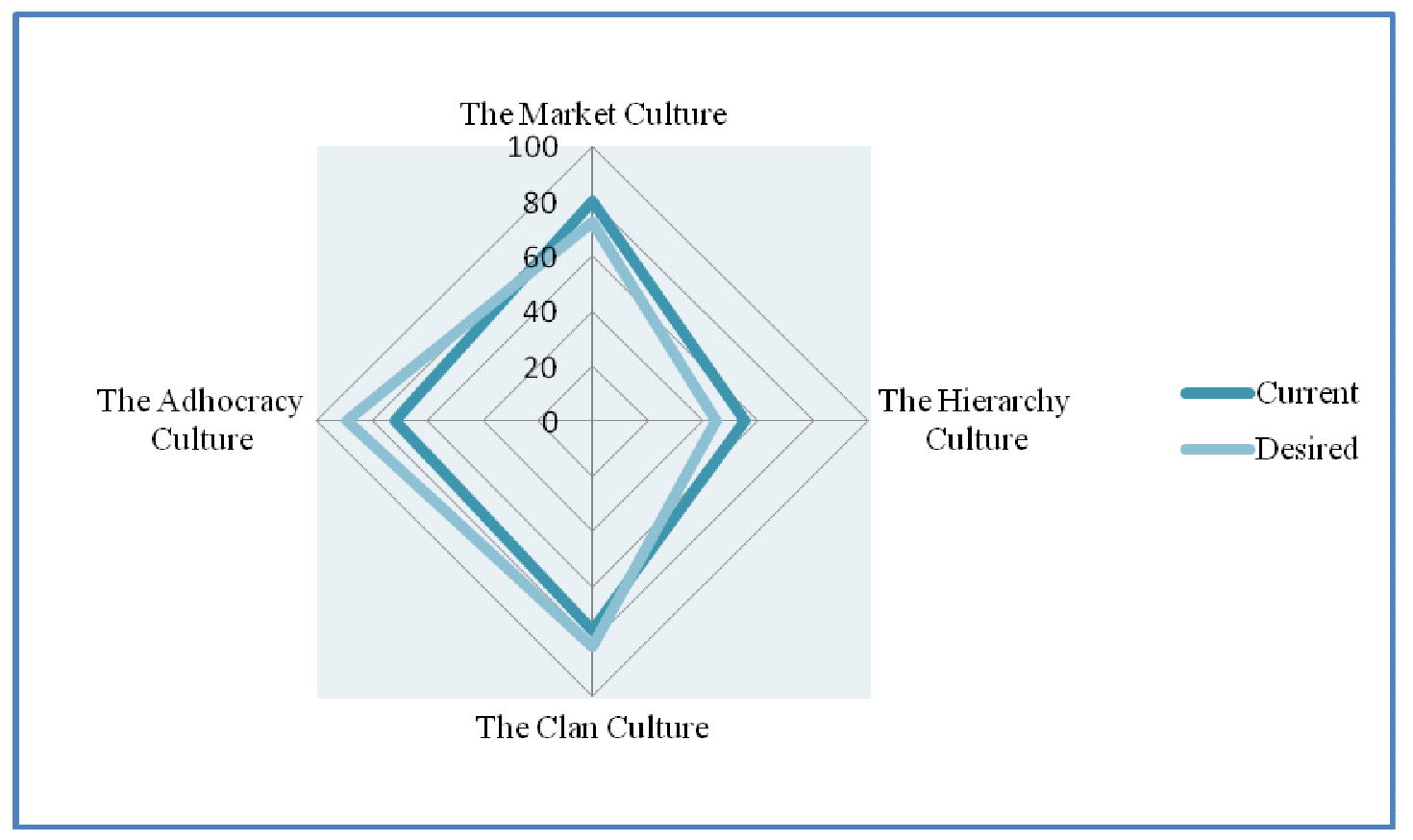

Fig. 2. Assessment of dominant organizational culture types

As HEI organizational culture research flourished, serious questions about interaction between this concept and innovations arose. Researchers argued that innovation is most likely to occur in educational institution with certain inherent elements: integrative structures, diversity, collaboration and teamwork values [18; 29]. Yet the findings of previous research contain some conclusive evidence regarding the role of specific organizational culture 
features in adopting information and communication technologies (ICTs) in higher education management. A body of international and domestic empirical research now exists which confirms the importance of developing and effective implementation of a technology-infused HEI management $[4 ; 18 ; 21 ; 27 ; 29]$.

Importantly, the $\mathrm{Ch} . \mathrm{Zu}$ and $\mathrm{N}$. Engels study pointed out that people's perceptions and adoption of innovations are regarded as a reflection of the organizational culture, as in a more supportive and innovative culture people are more encouraged to learn new things and try new methods, new work processes or new technologies [18]. Furthermore, the authors suggested that adoption of innovations, which include also ICTs, may be considered as an output of organizational culture as the components of this notion such as norms, values and beliefs shape the innovation adoption of an organization.

Additionally, J. Kotter and J. Heskett stated that exploration of the correlation between organizational culture and educational innovations can provide useful insights for HEI administrators [29].

E. Schein emphasized that leaders have a critical role in giving shape and reinforcing the culture of their organizations. International Society for Technology in Education developed Information Technology Standards for Educational Leaders. This document stated that "educational administrators inspire and lead development and implementation of a shared vision for comprehensive integration of technology to promote excellence and support transformation throughout the organization' [30]. In particular, a range of an educational manager' competencies include:

- Inspire and facilitate among all stakeholders a shared vision of purposeful change that maximizes use of digital-age resources to meet and exceed learning goals, support effective instructional practice, and maximize performance of district and school leaders.

- Engage in an ongoing process to develop, implement, and communicate technology-infused strategic plans aligned with a shared vision.

- Advocate on local, state and national levels for policies, programs, and funding to support implementation of a technology-infused vision and strategic plan [30].

Based on this document, we can conclude that aiming at continuous improvement of the organization through the effective use of information and technology resources, educational administrators should provide digital age leadership and management [30]. Several key competencies make realization of this task possible:

- Lead purposeful change to maximize the achievement of learning goals through the appropriate use of technology and media-rich resources.

- Collaborate to establish metrics, collect and analyze data, interpret results, and share findings to improve staff performance and student learning.

- Recruit and retain highly competent personnel who use technology creatively and proficiently to advance academic and operational goals.

- Establish and leverage strategic partnerships to support systemic improvement.

- Establish and maintain a robust infrastructure for technology including integrated, interoperable technology systems to support management, operations, teaching, and learning [30].

In order to investigate personal, sensitive and confidential information relating to the impact of organizational culture and ICT on the College performance, the in-depth interview of administrative staff and teachers of Lutsk Pedagogical College was conducted. A total of 30 college administrators and 33 teachers participated in this study. Among them, 51 were females, 12 were males. The questionnaire items were based mainly on the Information Technology Standards for Educational Leaders [30] and modified to fit to the nature of this study. The interview included the use of an expert assessment method to determine the level 
of competence of the administrative staff to meet technology-infused HEI management challenges. The descriptive statistics for study variables are presented in Table 3.

The results of the in-depth interview based on an expert assessment method indicated that the College administrators' competence in visionary leadership, according to the teachers' expert estimation, has got high rates in items 2 and 3. Importantly, the experts' estimation in both groups of respondents seemed to be not significantly different except items 1 and 6.

Administrative staff scored higher than teachers on views about supportive and teambuilding environment in the College (point 1), as well as on human resource policy development (point 6).

Table 3

\section{Descriptive statistics for study variables}

\begin{tabular}{|c|c|c|c|c|c|c|}
\hline \multirow[b]{2}{*}{$\begin{array}{l}\text { Technology- } \\
\text { infused competencies }\end{array}$} & \multicolumn{3}{|c|}{$\begin{array}{l}\text { Administrative staff's } \\
\text { expert self-estimation } \\
\text { (in \%) }\end{array}$} & \multicolumn{3}{|c|}{$\begin{array}{l}\text { Teachers' expert } \\
\text { estimation } \\
\quad \text { (in \%) }\end{array}$} \\
\hline & High & Middle & Low & High & Middle & Low \\
\hline \multicolumn{7}{|c|}{ Competence in visionary leadership } \\
\hline $\begin{array}{l}\text { 1. Inspire and facilitate among all stakeholders a } \\
\text { shared vision of purposeful change that } \\
\text { maximizes use of digital-age resources to meet } \\
\text { and exceed learning goals, support effective } \\
\text { instructional practice, and maximize performance } \\
\text { of district and college leaders. }\end{array}$ & 60.3 & 20.7 & 19.0 & 33.3 & 55.6 & 11.1 \\
\hline $\begin{array}{l}\text { 2. Engage in an ongoing process to develop, } \\
\text { implement, and communicate technology-infused } \\
\text { strategic plans aligned with a shared vision. }\end{array}$ & 74.6 & 25.4 & - & 79.3 & 20,7 & - \\
\hline $\begin{array}{l}\text { 3. Advocate on local, state and national levels for } \\
\text { policies, programs, and funding to support } \\
\text { implementation of a technology-infused vision } \\
\text { and strategic plan in the College. }\end{array}$ & 84.1 & 15.9 & - & 87.3 & 12.7 & - \\
\hline \multicolumn{7}{|c|}{ Competence in systemic improvement } \\
\hline $\begin{array}{l}\text { 4. Lead purposeful change to maximize the } \\
\text { achievement of learning goals through the } \\
\text { appropriate use of technology and media-rich } \\
\text { resources. }\end{array}$ & 61.9 & 38.1 & - & 92.1 & 7.9 & - \\
\hline $\begin{array}{l}\text { 5. Collaborate to establish metrics, collect and } \\
\text { analyze data, interpret results, and share findings } \\
\text { to improve staff performance and student } \\
\text { learning. }\end{array}$ & 50.8 & 49.2 & - & 54.0 & 46.0 & - \\
\hline $\begin{array}{l}\text { 6. Recruit and retain highly competent personnel } \\
\text { who use technology creatively and proficiently to } \\
\text { advance academic and operational goals. }\end{array}$ & 65.1 & 34.9 & - & 46.0 & 54.0 & - \\
\hline $\begin{array}{l}\text { 7. Establish and leverage strategic partnerships to } \\
\text { support systemic improvement. }\end{array}$ & 71.4 & 28.6 & - & 82.5 & 17.5 & - \\
\hline $\begin{array}{l}\text { 8. Establish and maintain a robust infrastructure for } \\
\text { technology including integrated, interoperable } \\
\text { technology systems to support management, } \\
\text { operations, teaching, and learning. }\end{array}$ & 65.0 & 35.0 & - & 68.3 & 31.7 & - \\
\hline
\end{tabular}

Regarding the implementation of ICTs, both administrative staff and teachers reported a high level of competence to establish and maintain a robust infrastructure for technology including integrated, interoperable technology systems to support management, operations, 
teaching, and learning. However, there were divergences between administrative staff and teachers. Teachers were more positive in this context.

The other part of the in-depth interview was self-developed for the purpose of this study. In particular, participants were asked some questions (a total of 10) in order to discover their opinions on the relationship between certain organizational culture type and ICT implementation in the College. Sample items were: 'How do you understand the relationship between innovation culture of the College and its organizational performance?'; 'What factors (elements) of organizational culture are important to encourage systemic improvement of technology-infused educational management?' According to the respondents' answers, adhocracy culture as the desirable organizational culture in the College can increase the organizational performance because it contains a set of values, beliefs, and pursuits that are susceptible to innovative, communicate technology-infused strategic plans and ideas.

Among the factors (elements) of organizational culture that positively influence the effective use of technology and media-rich resources in educational management, the respondents most frequently called the following ones: encouraging collaboration internally and externally, communication, supportive leadership, innovative training, environment of openness to experimentation and diversity, trust and teamwork.

From the questionnaire it is evident that the factors that negatively contributed towards the HEI innovative performance, as to the respondents' opinions, include: hierarchical structures, lack of shared vision of purposeful change, ICTs implementation not valued as organizational commitment, control-oriented human resource policy and others.

Finally, the respondents were of the opinion that creation of a digital-infused environment in the College that suggests the appropriate and strategic use of a wide spectrum of ICT application tools (Internet-based and web-based tools, hardware applications, and software applications) will help to establish effective, visionary, innovative, and successoriented leadership.

\section{CONCLUSIONS AND PROSPECTS FOR FURTHER RESEARCH}

Founded in psychological and sociological discourses, organizational culture has been repeatedly associated with effective educational management and quality assurance. Early research works suggested powerful effects from the simple idea that there is a strong connection between certain cultures and productivity of organization. According to the foreign and domestic research, there is no universal approach to define concept of organizational culture of a higher educational institution. Based on the recent research, we interpret organizational culture as a complex concept determined by the ability and readiness of a higher educational institution to mobilize the system of its internal and external resources (values, norms, and beliefs, traditions, rules etc.) in order to achieve strategic goals and mission, and to satisfy the requests of internal (students, teachers and staff) and external (government, quality assurance agencies, employers, parents) stakeholders.

The organizational culture construct has undergone multi-dimensional research and new theoretical models have emerged. In particular, The Competing Values Framework provides the definition of organizational culture grounded on the two value criteria: internal or external focus, and stability or flexibility. Based on these criteria, four types of organizational culture were defined: hierarchical, market, adhocracy and clan cultures.

The organizational culture research conducted by the authors at Lutsk Pedagogical College revealed that the current organizational culture of the College is more like market culture or rational culture. The respondents in the present study defined the adhocracy culture as the desirable organizational culture in the College. 
Notably, the results of the in-depth interview based on an expert assessment method indicated that teachers were moderately satisfied with the level of competence of the administrative staff to meet technology-infused HEI management challenges. Furthermore, the creation of a digital-infused environment in the College that suggests the appropriate and strategic use of a wide spectrum of ICT application tools, as to the respondents' opinions, is a necessary strategic solution in order to provide a desired organizational culture type establishment and effective, visionary, innovative, and success-oriented leadership in the College.

This investigation is a part of a vast research studying the relationship between ICTinfused educational management and $\mathrm{PhD}$ students' training effectiveness, which is seen as the basis for potential future research project.

\section{REFERENCES}

[1] K. S. Cameron, R. E. Quinn,. 'Diagnosing and Changing Organizational Culture: based on the competing values [Online]. Available: https://www.researchgate.net/file.PostFileLoader.html?id...assetKey. (in English).

[2] E. H. Schein, 'Organizational Culture and Leadership', Jossey-Bass, San Francisco, 1992, 2004. (in English).

[3] E. Schein, 'Innovative Cultures and Organizations', in: Allen, T. J. (Ed.), Morton, Scott, Information Technology and the Corporation of the 1990's: Research Studies, 1994, pp. 125-146. (in English).

[4] N. Morze, O. Kuz'mins'ka, 'Should the Head of an Educational Institution Earn the ICT-Competence?' [Online]. Available: http://elibrary.kubg.edu.ua/891/1/N_Morze_IITSH_6_NDLIO.pdf. (in Ukrainian).

[5] G. Bendermarcher, M. G. A. oude Egbrink et al., 'Unravelling quality culture in higher education: a realist review', Higher Education, Vol. 73, pp. 39-60, 2017. [Online]. Available: https://link.springer.com/article/10.1007/s10734-015-9979-2. (in English).

[6] L. Karamushka, Psychology of Educational Management. Kyiv, Ukraine: Lybid', 2014, 185 p. (in Ukrainian).

[7] M. A. Vilcea,. 'Quality Culture In Universities And Influences On Formal And Non-Formal Education', Procedia-Social and Behavioral Sciences, Vol. 163, pp. 148-152, 2014. [Online]. Available: http://www.sciencedirect.com/science/journal/18770428/163?sdc=1. (in English).

[8] M. Antić, An. Cerić 'Organizational Culture of Faculty of civil engineering, University of Zagreb' [Online]. Available: https://bib.irb.hr/datoteka/396954.Antic20Ceric.pdf. (in English).

[9] M. Kalnitska, 'Organizational culture Influence on the Innovative potential of the enterprise'. Visnyk Dnipropetrovs'koho universytetu. Seriya 'Menedzhment innovatsiy', 2015. [Online]. Available: https://mi-dnu.dp.ua/index.php/MI/article/view/69. (in Ukrainian).

[10] V. Zotic, 'Organizational culture of the Head of an Educational Institution'. [Online]. Available: http://umo.edu.ua/images/content/nashi_vydanya/stud_almanah/v_1/19.pdf. (in Ukrainian).

[11] N. Horbenko, 'Corporate Culture of Modern University: Approaches to Definition Essence'. Hrani. Seriya 'Filosofiya', 2014. [Online]. Available: http://nbuv.gov.ua/UJRN/Grani_2014_8_10. (in Ukrainian).

[12] T. Koicheva, 'Diagnostics of Organizational Culture of University Teachers', Science and Education. 2015. [Online]. Available: http://nbuv.gov.ua/UJRN/NiO_2015_6_10. (in Ukrainian).

[13] T. Beneda, 'Corporate culture as a precondition for competitiveness of an educational institution' [Online]. Available: irbis-nbuv.gov.ua/.../cgiirbis_64. (in Ukrainian).

[14] M. L. Lacatus, 'Organizational Culture in Contemporary University', Procedia - Social and Behavioral Sciences.Vol. 76, pp. 421-425, 2013. [Online]. Available: http://www.sciencedirect.com/.../76?sdc=1. (in English).

[15] C. O'Reilly, 'Corporations, culture, and commitment: Motivation and social control in organizations', California Management Review, Vol. 31(4), pp. 9-25, 1989. (in English).

[16] G. A. Marcoulides, R. H. Heck and C. Papanastasiou, 'Student perceptions of school culture and achievement:Testing the invariance of a model', International Journal of Educational Management, Vol. 19 (2), pp. 140-152, 2005. (in English).

[17] R. H. Hofman, W. H. Hofman and H.Guldemond, 'School governance, culture, and student achievement', International Journal of Leadership in Education, Vol. 5 (3), pp. 249-272, 2002. (in English). 
[18] Ch. Zhu, N. Engels,. 'Organizational Culture and Instructional Innovations in Higher Education: Perceptions and Reactions of Teachers and Students', Educational Management Administration \& Leadership, Vol. 42 (1), pp. 136-158, 2014. [Online]. Available: http://journals.sagepub.com/doi/pdf. (in English).

[19] T. Becher, 'Academic Tribes and Territories: Intelectual Enquiry and the Cultures of Disciplines', Buckingham: Open University Press, 1989. (in English).

[20] N. Fjortoft, J. Smart,. 'Enhancing Organizational Effectiveness: the importance of culture type and mission agreement', Higher Education, Vol. 27, pp. 429-447, 1994. (in English).

[21] B. Sporn, 'Managing University Culture: an Analyses of the Relationship Between Institutional Culture and Management Approaches', Higher Education. Vol. 32, pp. 41-61, 1996. (in English).

[22] Ian McNay, 'Universities going international: choices, cautions and conditions', in P. Blok (ed.), Policy and Policy Implementation in Internationalisation of Higher Education, Amsterdam: EAIE, 1995. (in English).

[23] O. Beytekin, et al., 'The Organizational Culture At The University', International Journal of Educational Researchers. Educational Research Association, Vol. 2(1), pp. 1-13, 2010. (in English).

[24] K. S. Cameron, S. J. Freeman, 'Cultural Congruence, Strength and Type: Relationships to Effectiveness', Research in Organizational Change and Development, Vol. 5, pp. 23-58, 1991. (in English).

[25] M. J. Millington, J. C. Schultz, 'The challenge of organizational culture in quality assurance implementation', Journal of Rehabilitation Administration, Vol. 33 (2), pp.121-130, 2009. (in English).

[26] D. Denison, A. Mishra (1995), 'Toward a theory of organizational culture and effectiveness'. Organizational Science, Vol. 6(2), pp. 204-223, 1995. (in English).

[27] I. Lapina, D. Kairiša, D. Aramina, 'Role of Organizational Culture in the Quality Management of University', Procedia-Social and Behavioral Sciences, Vol. 213, pp. 770-774, 2015. [Online]. Available: http://www.sciencedirect.com/science/journal/18770428/213?sdc=1. (in English).

[28] J. Jameson, 'Changing Leadership Identities: the Role of Trust and Organisational Cultures in a Recessionary UK Higher Education Policy Context', SRHE Higher Educational Policy Network, 2011. (in English).

[29] J. P. Kotter and J. L. Heskett, 'Corporate Culture and Performance’, New York: The Free Press, 1992. (in English).

[30] Information Technology Standards for Educational Leaders. International Society for Technology in Education, 2009. [Online]. Available: https://www.iste.org/standards/standards/standards-foradministrators (in English).

\title{
ТЕОРІЯ ТА ПРАКТИКА ФОРМУВАННЯ ОРГАНІЗАЦИЙНОЇ КУЛЬТУРИ ВИЩОГО НАВЧАЛЬНОГО ЗАКЛАДУ У КОНТЕКСТІ ІНФОРМАТИЗАЦЇ̈ МЕНЕДЖМЕНТУ
}

\author{
Бойчук Петро Микитович \\ кандидат педагогічних наук, директор \\ Луцький педагогічний коледж, м. Луцьк, Україна \\ ORCID ID 0000-0003-4863-980X \\ petroboychuk@i.ua

\section{Фаст Ольга Леонідівна} \\ кандидат педагогічних наук, докторант \\ Східноєвропейський національний університет імені Лесі Українки, м. Луцьк, Україна \\ ORCID ID 0000-0001-7216-0044 \\ olhafast.ua@gmail.com
}

Анотація. Стаття висвітлює аналіз наукових джерел, методологічні основи та практичні здобутки у вивченні взаємозв'язків між типом організаційної культури ВНЗ та компетентністю менеджерів щодо інформатизації системи управління у вищій школі. На підгрунті аналізу закордонних і вітчизняних досліджень авторами дефініційовано сутність поняття організаційної культури вищого навчального закладу. За результатами емпіричних досліджень з'ясовано, що респонденти відносять актуальну організаційну культуру навчального закладу до ринково-зорієнтовано типу; водночас бажаним типом 
організаційної культури виявився адхократичний тип. Використання методів інтерв'ю й експертної оцінки дозволило встановити задоволеність респондентів рівнем компетентності адміністрації навчального закладу щодо реалізації технологічно-місткого освітнього менеджменту.

Ключові слова: організаційна культура; технологічно-місткий освітній менеджмент; інформаційно-комунікаційні технології і засоби; управління.

\title{
ТЕОРИЯ И ПРАКТИКА ФОРМИРОВАНИЯ ОРГАНИЗАЦИОННОЙ КУЛЬТУРЫ ВЫСШЕГО УЧЕБНОГО ЗАВЕДЕНИЯ В КОНТЕКСТЕ ИНФОРМАТИЗАЦИИ МЕНЕДЖМЕНТА
}

\author{
Бойчук Петр Никитич \\ кандидат педагогических наук, директор \\ Луцкий педагогический колледж, г. Луцк, Украина \\ ORCID ID 0000-0003-4863-980X \\ petroboychuk@i.ua \\ Фаст Ольга Леонидовна \\ кандидат педагогических наук, докторант \\ Восточноевропейский национальный университет имени Леси Украинки, г. Луцк, Украина \\ ORCID ID 0000-0001-7216-0044 \\ olhafast.ua@gmail.com
}

\begin{abstract}
Аннотация. Статья освещает анализ научных источников, методологические основы и практические достижения в изучении взаимосвязей между типом организационной культуры вуза и компетентностью менеджеров в информатизации системы управления в высшей школе. На основе анализа зарубежных и отечественных исследований авторами интерпретируется сущность понятия организационной культуры высшего учебного заведения. По результатам эмпирических исследований установлено, что респонденты относят актуальную организационную культуру учебного заведения к рыночно ориентированному типу; одновременно желаемым типом организационной культуры оказался адхократический тип. Использование методов интервью и экспертной оценки позволило установить удовлетворенность респондентов уровнем компетентности администрации учебного заведения по реализации технологически емкого образовательного менеджмента.
\end{abstract}

Ключевые слова: организационная культура; технологически емкий образовательный менеджмент; информационно-коммуникационные технологии и средства; управление.

\section{(cc) BY-NC-SA}

This work is licensed under Creative Commons Attribution-NonCommercial-ShareAlike 4.0 International License. 